\title{
Diversity of Butterflies (Lepidoptera: Papilionoidea) in a Temperate Forest Ecosystem, Binsar Wildlife Sanctuary, Indian Himalayan Region
}

\author{
M. K. Arya $\dagger$, A. Verma and P. Tamta \\ Insect Biodiversity Laboratory, Department of Zoology, D.S B. Campus, Kumaun University, Nainital-263002, \\ Uttarakhand, India \\ $\dagger$ Corresponding author: M. K. Arya; dr.manojkumar19@rediffmail.com
}

Nat. Env. \& Poll. Tech. Website: www.neptjournal.com

Received: 30-09-2019

Revised: $27-10-2019$

Accepted: 11-12-2019

Key Words:

Diversity of butterflies

Conservation

Forest ecosystem

Protected area

\begin{abstract}
Observational studies aiming to elucidate the differences in butterfly fauna along altitudinal gradients in Binsar Wildlife Sanctuary were carried out during 2014-2015. The study revealed a total of 2591 individuals belonging to 46 species and 35 genera under six families of butterflies. Four species under legal protection were also recorded. Family Nymphalidae was the most dominant with 22 species followed by Pieridae (12 species), Lycaenidae (4 species), Papilionidae, Riodinidae (3 species each) and Hesperiidae (2 species). Higher values of species richness, abundance and diversity were recorded for transects at the low altitudinal site. Species such as Aglais caschmirensis (Fruhstorfer), Pieris canidia indica Evans, Pieris brassicae Linnaeus and Byasa polyeuctes letincius (Fruhstorfer) were most abundant, while Dodona ouida Hewitson, Udara dilectus Moore, Aulocera padama Kollar, Talicada nyseus (Guérin-Méneville) and Argynnis childreni (Gray) accounting for $1.38 \%$ of the total individuals of butterflies, were least abundant species during the study period. Results of the study on diversity and distributions of butterflies are preliminary ones which would help in strengthening the biodiversity status of the Binsar Wildlife Sanctuary.
\end{abstract}

\section{INTRODUCTION}

The Indian Himalayan Region is a repository for rich biological diversity and to ensure its proper conservation, protected areas in the form of Biosphere Reserves, National Parks, Sanctuaries and Conservation Reserves have been established (Rodgers \& Panwar 1988). Uttarakhand, the newest Himalayan state in India, stretching across $53,485 \mathrm{sq} \mathrm{km}$, is blessed with ample natural resources and harbours a charismatic range of biodiversity. Almost $64.79 \%$ of its total geographical area is designated as forest area while forest cover is limited to $35 \%$ of the geographical area (FSI 2011). In recent decades, the state has witnessed a plethora of natural disasters aggravated by man-made factors which have affected the ecology of the region at a large scale (Tayal et al. 2015).

Despite the central role of nature reserves in global efforts for conservation of biodiversity, policies such as downgrading and downsizing of the protected areas have been contentiously adopted, especially in developing countries of the world (Mascia \& Pailler 2010). Based on national priorities, the disparity in ranking the importance of protected areas underscore the need for resilient and robust conservation strategies which must be adopted in the present era with an unprecedented rate of biodiversity loss and extinction. The protected areas located in the Indian Himalayan Region especially those which are low profiled ones hold immense potential to enhance the components of biological representativeness, integrity and human sustenance in the region (Rawal \& Dhar 2001). Binsar Wildlife Sanctuary (hereafter referred as BWLS), which is a natural habitat for many species of flora and fauna has recently received the attention of the government and non-government organizations and is being developed as a hot tourist destination in the calm and pristine environment of the Kumaon Himalaya. From different in situ conservation sites of the Indian Himalayan Region, numerous scientific records regarding distribution and diversity of butterflies have been published by various workers (Arora 1994, Arora 1995, Uniyal \& Mathur 1998, Joshi et al. 2004, Joshi 2007, Joshi \& Arya 2007, Singh 2009, Joshi et al. 2008, Kumar 2008, Bhardwaj \& Uniyal 2013, Pandey et al. 2013, Tewari \& Rawat 2013, Qureshi et al. 2014, Arya 2015, Sondhi \& Kunte 2016, Singh \& Sondhi 2016, Arya \& Dayakrishna 2017, Kumar et al. 2017). Till date, no comprehensive approaches have been made to understand butterfly diversity of the BWLS. Considering the importance of butterflies as efficient pollinators essential for continuity of the ecosystem services (Tiple et al. 2006), their ecological roles in the food web and as indicators (Kunte 2000, Hill et al. 2002), for promoting conservation programs (New 2011) and ecotourism as well (Arya et al. 2018), it is imperative to evaluate species composition, status and habitat preferences of butterflies from the present region. Moreover, butterflies, in 
particular, are facing a threat of range contraction both across the latitudinal and altitudinal gradients due to global climate change. Thus steps of inventorizing biodiversity patterns along such gradients have strong conservation implications (Acharya \& Vijayan 2015). Keeping this in view, the present study was primarily aimed at examining species composition and diversity of butterflies along altitudinal gradients in the BWLS for their future conservation in the protected area. The present study also aims to generate information for conservation authorities regarding the development and management of the sanctuary.

\section{MATERIALS AND METHODS}

\section{Study Area}

BWLS, with a total geographical area of $47.67 \mathrm{sq} \mathrm{km}$ is located in Almora and Bageshwar districts of the state Uttarakhand (Fig. 1). The sanctuary lies under geographical coordinates $29^{\circ} 39^{\prime}-29^{\circ} 44^{\prime} \mathrm{N}$ and $79^{\circ} 41^{\prime}-79^{\circ} 49^{\prime} \mathrm{E}$ and the altitude ranges between 1200 to $2500 \mathrm{~m}$ above sea level. BWLS represents one of the oldest protected landscapes in the Kumaon Himalayan region characterized by hilly terrains, ravines and ridges providing a wide array of microhabitats to diverse flora and fauna. Before India's independence in 1947, the study area was notified as the 'Protected Forest' in 1893 and later its status was revived as the 'Reserve Forest' in 1897. After independence, the status was upgraded to 'Wildlife Sanctuary' by the Government of India in 1988. The region of BWLS is also renowned for its religious, historical, cultural and recreational values. The sanctuary is earmarked with two zones, core zone (4 sq km) and a buffer zone (43.67 sq km). Human activities are restricted in the core zone of the sanctuary which comprises biodiversity of strategic importance. The vegetation is represented by a characteristic moist temperate type of forest surrounded by villages and agricultural lands. The sanctuary is home to 40 species of trees, 26 shrubs, 50 herbs, 19 grasses and six ferns (Ilyas 1998) which are congenial for the survival of butterflies. The monthly mean temperature ranges from 2.2 to $15.5^{\circ} \mathrm{C}$ during winter and from 17.20 to $26.6^{\circ} \mathrm{C}$ during the summer season. The annual mean precipitation is about 1041.8 mm (Kala \& Majila 2013).

Based on altitudinal variations, two distinct sites were selected for the sampling of butterflies. Two permanent transects with distinct habitat features each of length $800 \mathrm{~m}$ on different altitudes were laid down at each study site. The characteristic features of each transect selected in the study site have been summarized in Table 1. Human activities such as agriculture practicing, livestock grazing and tourism are frequent at the lower altitudinal site, while the higher altitudinal site remained least disturbed during the observations made in the present study.

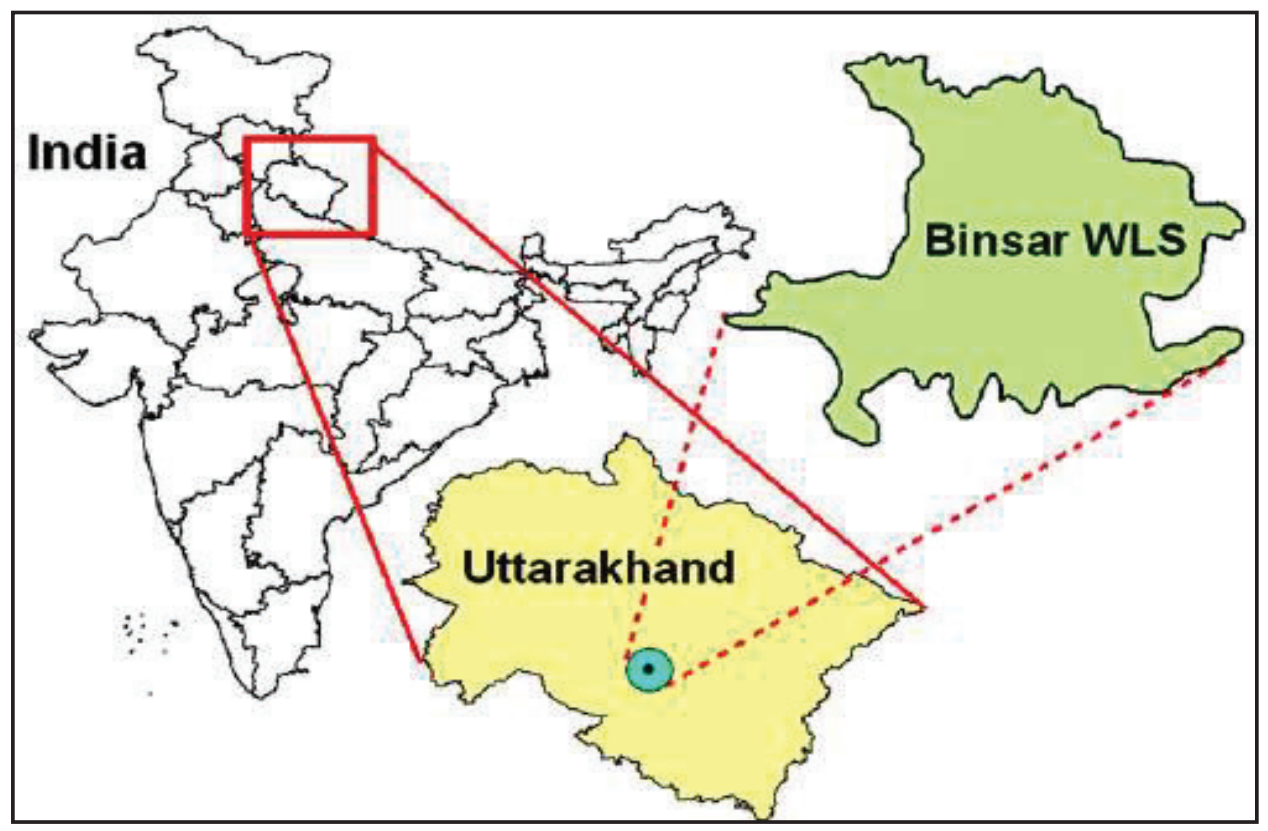

Fig. 1: Line drawing map showing the location of BWLS. 


\section{Sampling of Butterflies}

Census on butterfly populations was undertaken in consecutive four days of each month at different sites of BWLS from July 2014 to June 2015. Both transects at lower altitudinal zone were walked with constant pace for one hour each between 08:30 $\mathrm{hr}$ to $11: 30 \mathrm{hr}$ and on the next day, between 12:00 hr to 15:00 hr for each sampling period. The same sampling method was followed for each transect at higher altitudinal zone from the next two consecutive days. 'Pollard Walk' method was adopted for the sampling of butterflies during cloudless days (Pollard 1979, Pollard \& Yates 1993). The individuals of butterflies were counted up to $5 \mathrm{~m}$ on both sides of each transect. Identification of butterflies was carried out in the field visually through photography and with the assistance of the field guides (Haribal 1992, Kehimkar 2014, Sondhi \& Kunte 2018). Butterflies were neither killed nor collected during the present study. In the case, sight records where the identification was not possible, butterflies were captured by using the aerial net avoiding any harm and identified subsequently released at the same spot of capture. The climatic factors such as monthly temperature and relative humidity associated with each transect were also recorded using thermo-hygrometer.

\section{Status of Butterflies}

To determine the local status of the identified butterflies in the sanctuary, species were characterized into four groups based on the overall number of sightings in the study area, namely, fairly common (with more than 50 sightings), common (between 21-50 sightings), uncommon (between 11-20 sightings) and rare (with less than 10 sightings), respectively.

\section{Similarity Index}

The species composition between transects was measured using the formula of Magurran (1988): Similarity index (C) $=2 \mathrm{c} / \mathrm{a}+\mathrm{b}$

Where, $a$ is the number of species in area $A ; b$ is the number of species in area $\mathrm{B} ; \mathrm{c}$ is the number of shared species between the two areas.

\section{Statistical Analysis}

Data were pooled to compare the diversity of butterflies across different sites along altitudes. Various measures of diversity (Simpson, Shannon-Weiner, evenness, Margalef and Berger Parker) were computed by using the program PAST 3.4 (Hammer et al. 2014). Bray Curtis cluster and their similarity matrix of butterflies across different transects were analyzed with the help of ecological analysis software, BIODIVERSITY PRO VERSION 2 (Lambshead et al. 1997).

\section{RESULTS AND DISCUSSION}

During the study, a total number of 2591 individuals belonging to 46 species and 35 genera under six families of butterflies were counted from four permanent transects with 24 species common to all transects (Tables 2 and 3). Family Nymphalidae was the most dominant with 18 genera and 22 species followed by Pieridae ( 8 genera, 12 species), Lycaenidae (4 genera, 4 species), Papilionidae (2 genera, 3 species), Riodinidae (1 genus, 3 species) and Hesperiidae (2 genera, 2 species). Such variations at both generic and species levels, especially among butterfly communities, reflect the habitat complexity and range of larval host plants available in the

Table 1: Characteristic features of selected study sites in the BWLS.

\begin{tabular}{|c|c|c|c|c|c|}
\hline Sampling Sites & & $\begin{array}{l}\text { Altitude } \\
\text { (m a.s.1.) }\end{array}$ & $\begin{array}{l}\text { Temp. Range } \\
\left({ }^{\circ} \mathrm{C}\right)\end{array}$ & $\begin{array}{l}\text { Relative } \\
\text { Humidity } \\
(\%)\end{array}$ & Habitat characteristics and major vegetation \\
\hline \multirow[t]{2}{*}{$\begin{array}{l}\text { Low Altitude } \\
(1200-1700 \mathrm{~m})\end{array}$} & $\begin{array}{l}\text { Transect } 1 \\
\text { (Ayarpani) }\end{array}$ & 1250 & $9-29$ & $30-75$ & $\begin{array}{l}\text { Pine dominant with large canopy gaps forest; } \\
\text { Pinus roxburghii, Pyrus pashia, Myrica esculenta, } \\
\text { Quercus leucotrichophora, Cornus macrophylla, } \\
\text { Berberis asiatica }\end{array}$ \\
\hline & $\begin{array}{l}\text { Transect } 2 \\
\text { (Binneshwar Mahadev) }\end{array}$ & 1650 & $8.3-27$ & $56-88$ & $\begin{array}{l}\text { Oak forest with moderate canopy gaps; Quercus } \\
\text { semicarpifolia, Quercus leucotrichophora, Quercus } \\
\text { floribunda, Aesculus indica, Juglans regia, Rubus } \\
\text { ellipticus }\end{array}$ \\
\hline \multirow[t]{2}{*}{$\begin{array}{l}\text { High Altitude } \\
(2100-2500 \mathrm{~m})\end{array}$} & $\begin{array}{l}\text { Transect } 3 \\
\text { (Jhandidhar) }\end{array}$ & 2100 & $6-26$ & $57-89$ & $\begin{array}{l}\text { Oak-Deodar forest with dense canopy cover; Quer- } \\
\text { cus semicarpifolia, Quercus floribunda, Cedrus } \\
\text { deodara, Daphne papyracea, Deutzia staminea }\end{array}$ \\
\hline & $\begin{array}{l}\text { Transect } 4 \\
\text { (Zero point) }\end{array}$ & 2500 & $5.5-24$ & $57.8-90$ & $\begin{array}{l}\text { Hilltop grassland surrounded with Quercus semi- } \\
\text { carpifolia, Rhododendron arboreum and Cedrus } \\
\text { deodara }\end{array}$ \\
\hline
\end{tabular}


Table 2: Butterfly species composition and their relative abundances at four transects in BWLS.

\begin{tabular}{|c|c|c|c|c|c|c|c|c|c|}
\hline \multirow[t]{2}{*}{ S.No. } & \multirow{2}{*}{$\begin{array}{l}\text { Lepidoptera: } \\
\text { Papilionoidea }\end{array}$} & \multicolumn{3}{|c|}{ Low Altitude Site } & \multicolumn{3}{|c|}{ High Altitude Site } & \multirow{2}{*}{$\begin{array}{l}\text { Relative Abun- } \\
\text { dance }(\%)\end{array}$} & \multirow[t]{2}{*}{ Status } \\
\hline & & T 1 & T 2 & Total & T 3 & $\mathrm{~T} 4$ & Total & & \\
\hline & Family: Nymphalidae & & & & & & & & \\
\hline 1 & Aglais cashmirensis (Fruhstorfer) & 170 & 120 & 290 & 90 & 48 & 138 & 16.51 & $\mathrm{FC}$ \\
\hline 2 & Argynnis childreni (Gray) & 6 & 3 & 9 & - & - & - & 0.34 & $\mathrm{R}$ \\
\hline 3 & Argynnis hyperbius Linnaeus & 17 & 11 & 28 & 10 & 6 & 16 & 1.69 & $\mathrm{C}$ \\
\hline 4 & Aulocera swaha Kollar & 35 & 16 & 51 & 15 & 4 & 19 & 2.70 & $\mathrm{FC}$ \\
\hline 5 & Aulocera padma Kollar & - & - & - & 6 & 2 & 8 & 0.30 & $\mathrm{R}$ \\
\hline 6 & Callerebia annada (Moore) & 17 & 16 & 33 & 12 & 5 & 17 & 1.92 & $\mathrm{C}$ \\
\hline 7 & Callerebia scanda (Kollar) & 12 & 10 & 22 & 8 & 7 & 15 & 1.42 & $\mathrm{C}$ \\
\hline 8 & Danaus chryssippus (Linnaeus) & 14 & 6 & 20 & - & - & - & 0.77 & $\mathrm{UC}$ \\
\hline 9 & Euploea core (Cramer) & 35 & 16 & 51 & - & - & - & 1.96 & $\mathrm{FC}$ \\
\hline 10 & Junonia iphita Cramer & 17 & 13 & 30 & 11 & 10 & 21 & 1.96 & $\mathrm{FC}$ \\
\hline 11 & Kallima inachus Boisduval & - & - & - & 20 & 9 & 29 & 1.11 & $\mathrm{C}$ \\
\hline 12 & Kaniska canace (Linnaeus) & 12 & 5 & 17 & 4 & 2 & 6 & 0.23 & $\mathrm{C}$ \\
\hline 13 & Lasiommata schakra (Kollar) & 8 & 3 & 11 & - & - & - & 0.42 & $\mathrm{UC}$ \\
\hline 14 & Lethe verma Kollar & 20 & 9 & 29 & 7 & 6 & 13 & 1.62 & $\mathrm{C}$ \\
\hline 15 & Neptis sankara (Kollar) & 8 & 4 & 12 & 2 & 2 & 4 & 0.61 & $\mathrm{UC}$ \\
\hline 16 & Neptis zaida Westwood & 20 & - & 20 & 10 & 5 & 15 & 1.35 & $\mathrm{C}$ \\
\hline 17 & Peudergolis wedah (Kollar) & 12 & 6 & 18 & - & - & - & 0.69 & $\mathrm{UC}$ \\
\hline 18 & Phalanta phalantha (Drury) & 28 & 14 & 42 & - & - & - & 1.62 & $\mathrm{C}$ \\
\hline 19 & Sephisa dichroa (Kollar) & 6 & 2 & 8 & 3 & 2 & 5 & 0.50 & $\mathrm{UC}$ \\
\hline 20 & Vanessa cardui Linnaeus & 25 & 11 & 36 & 10 & 7 & 17 & 2.04 & $\mathrm{FC}$ \\
\hline 21 & Vanessa indica Herbst & 20 & 10 & 30 & 10 & 5 & 15 & 1.73 & $\mathrm{C}$ \\
\hline \multirow[t]{2}{*}{22} & Ypthima nareda nareda (Kollar) & 13 & 4 & 17 & 3 & 1 & 4 & 0.81 & $\mathrm{C}$ \\
\hline & Family: Pieridae & & & & & & & & \\
\hline 23 & Belenois aurota (Fabricius) & 36 & 14 & 50 & - & - & - & 1.92 & $\mathrm{C}$ \\
\hline 24 & Catopsilia pomona Linnaeus & 40 & 20 & 60 & - & - & - & 2.31 & $\mathrm{FC}$ \\
\hline 25 & Colias fieldi Menetries & 17 & 8 & 25 & 8 & 7 & 15 & 1.54 & $\mathrm{C}$ \\
\hline 26 & Eurema brigitta rubella Wallace & 12 & 6 & 18 & 9 & 5 & 14 & 1.23 & $\mathrm{C}$ \\
\hline 27 & Eurema hecabe Linnaeus & 26 & 12 & 38 & - & 5 & 5 & 1.65 & $\mathrm{C}$ \\
\hline 28 & Eurema laeta Boisduval & 16 & 7 & 23 & 10 & 6 & 16 & 1.50 & $\mathrm{C}$ \\
\hline 29 & $\begin{array}{l}\text { Gonepteryx rhamni nepalensis } \\
\text { Linnaeus }\end{array}$ & 33 & 17 & 50 & 15 & 9 & 24 & 2.85 & FC \\
\hline 30 & Aporia agathon agathon (Gray) & - & 10 & 10 & 10 & 2 & 12 & 0.84 & $\mathrm{C}$ \\
\hline 31 & Aporia agathon phryxe (Boisduval) & 18 & 9 & 27 & - & - & - & 1.04 & $\mathrm{C}$ \\
\hline 32 & Pieris brassicae Linnaeus & 65 & 50 & 115 & 42 & 38 & 80 & 7.52 & $\mathrm{FC}$ \\
\hline 33 & Pieris canidia indica Evans & 100 & 96 & 196 & 82 & 38 & 120 & 12.19 & $\mathrm{FC}$ \\
\hline \multirow[t]{2}{*}{34} & Pontia daplidice (Linnaeus) & - & - & - & 12 & 3 & 15 & 0.57 & $\mathrm{UC}$ \\
\hline & Family: Lycaenidae & & & & & & & & \\
\hline 35 & Heliophorus sena Kollar & 64 & 59 & 123 & 33 & 22 & 55 & 6.86 & $\mathrm{FC}$ \\
\hline 36 & Lycaena panava (Kollar) & 31 & 16 & 47 & - & 10 & 10 & 2.04 & $\mathrm{FC}$ \\
\hline
\end{tabular}




\begin{tabular}{|c|c|c|c|c|c|c|c|c|c|}
\hline \multirow[t]{2}{*}{ S.No. } & \multirow{2}{*}{$\begin{array}{l}\text { Lepidoptera: } \\
\text { Papilionoidea }\end{array}$} & \multicolumn{3}{|c|}{ Low Altitude Site } & \multicolumn{3}{|c|}{ High Altitude Site } & \multirow{2}{*}{$\begin{array}{l}\text { Relative Abun- } \\
\text { dance }(\%)\end{array}$} & \multirow[t]{2}{*}{ Status } \\
\hline & & T 1 & T 2 & Total & Т 3 & $\mathrm{~T} 4$ & Total & & \\
\hline 37 & Talicada nyseus (Guérin-Méneville) & 6 & 2 & 8 & 1 & - & 1 & 0.34 & $\mathrm{R}$ \\
\hline \multirow[t]{2}{*}{38} & Udara dilectus Moore & - & - & - & 5 & - & 5 & 0.19 & $\mathrm{R}$ \\
\hline & Family: Papilionidae & & & & & & & & \\
\hline 39 & $\begin{array}{l}\text { Byasa polyeuctes letincius (Fruh- } \\
\text { storfer) }\end{array}$ & 37 & 30 & 67 & 10 & 7 & 17 & 3.24 & FC \\
\hline 40 & Papilio bianor polyctor Boisduval & 23 & 20 & 43 & 15 & 7 & 22 & 2.50 & FC \\
\hline \multirow[t]{2}{*}{41} & Papilio polytes Linnaeus & 29 & 21 & 50 & 10 & - & 10 & 2.31 & FC \\
\hline & Family: Riodinidae & & & & & & & & \\
\hline 42 & Dodona durga durga (Kollar) & 20 & 10 & 30 & 10 & 5 & 15 & 1.73 & $\mathrm{C}$ \\
\hline 43 & Dodona eugenes Bates & 12 & 6 & 18 & 6 & 3 & 9 & 1.04 & $\mathrm{C}$ \\
\hline \multirow[t]{2}{*}{44} & Dodona ouida Hewitson & 5 & - & 5 & - & - & - & 0.19 & $\mathrm{R}$ \\
\hline & Family: Hesperiidae & & & & & & & & \\
\hline 45 & Ochlodes brahma Moore & 10 & 6 & 16 & - & - & - & 0.61 & UC \\
\hline \multirow[t]{2}{*}{46} & Tagiades cohaerens cynthia Evans & 6 & 5 & 11 & - & - & - & 0.42 & $\mathrm{UC}$ \\
\hline & Total & 1101 & 703 & 1804 & 499 & 288 & 787 & & \\
\hline
\end{tabular}

Abbreviations: $\mathrm{T} 1=$ Transect $1 ; \mathrm{T} 2=$ Transect $2 ; \mathrm{T} 3=$ Transect $3 ; \mathrm{T} 4=$ Transect $4 ; \mathrm{FC}=$ Fairly common; $\mathrm{C}=\mathrm{Common} ; \mathrm{UC}=\mathrm{Uncommon}$ and $\mathrm{R}=\mathrm{Rare}$

region (Chowdhury 2014). In terms of the total number of individuals reported, Nymphalidae was the most dominant family ( $43.07 \%$ of the total number of individuals), followed by Pieridae (35.24\%), Lycaenidae $(9.61 \%)$, Papilionidae (8.07\%), Riodinidae $(2.97 \%)$ and Hesperiidae (1.04\%), respectively (Table 3). Such domination of Nymphalid butterflies might be due to the polyphagous nature of their larval forms and similar pattern with the predominance of family Nymphalidae have also been extensively registered from different protected areas of Uttarakhand (Joshi 2007, Joshi \& Arya 2007, Joshi et al. 2008, Kumar 2008, Singh 2009, Bhardwaj \& Uniyal 2013, Uniyal et al. 2013). As far as knowledge on butterfly diversity from BWLS is concerned, it is important to mention here that the present study is the first constituting systematic survey based on standardized methods. Due to differences in habitat and sampling time and efforts, it would be inappropriate to make quantitative comparisons in the diversity of butterflies from other protected areas of Uttarakhand. However, the richness of butterfly fauna in BWLS was fairly higher when compared to the nearby protected area, Askot Wildlife Sanctuary, with known records of 32 species so far (Pandey et al. 2013). Similarly, Arya \& Dayakrishna (2017) reported 36 species of butterflies from Nandhaur Wildlife Sanctuary located at foothills of the Kumaon Himalayan Region. Also, Smetacek (2012) reported 243 species of butterflies from Nainital district in the Kumaon region during 1951-2010, which is a long term survey compared to the short term survey conducted in the current research.

Based on the observations, Aglais caschmirensis Kollar was the most abundant and frequently sighted species in all transects constituting $16.51 \%$ of the total individuals of butterflies recorded in the present study. The other frequently observed butterflies in the sanctuary includes species such as Aulocera swaha Kollar, Junonia iphita Cramer, Vanessa cardui Linnaeus, Gonepteryx rhamni nepalensis Linnaeus, Pieris brassicae Linnaeus, Pieris canidia indica Evans, Heliophorus sena Kollar, Byasa polyeuctes letincius

Table 3: Number of genera, species and individuals of different families of butterflies recorded from BWLS.

\begin{tabular}{|lllll|}
\hline \multirow{2}{*}{ S. No. } & Family & \multicolumn{2}{c|}{} \\
\cline { 3 - 5 } & & Genera & Species & Individuals \\
\hline 1 & Nymphalidae & 18 & 22 & 1116 \\
2 & Pieridae & 8 & 12 & 913 \\
3 & Lycaenidae & 4 & 4 & 249 \\
4 & Papilionidae & 2 & 3 & 209 \\
5 & Riodinidae & 1 & 3 & 77 \\
6 & Hesperiidae & 2 & 2 & 27 \\
\hline
\end{tabular}


(Fruhstorfer) and Papilio bianor polyctor Boisduval. These species exhibited a declining trend in their abundance across transects that were laid along increasing altitudes. On the other hand, five species were recorded as rare including Dodona ouida Hewiston, Udara dilectus Moore, Aulocera padama Kollar, Talicada nyseus (Guerin-Meneville) and Argynnis childreni (Gray), which altogether accounted for $1.38 \%$ of the total individuals of butterflies recorded during the study period. These species were reported rarely from one or two transects. Butterfly species composition of sites at a lower and higher elevation was rather similar (similarity index of 0.789) and this was true across all three dominant families with similarity indices of Nymphalidae 0.777, Pieridae 0.8 and Lycaenidae 0.857.

Transect 1 supported maximum numbers of species of butterflies (41 species), followed by Transect 2 ( 40 species), Transect 3 (32 species) and Transect 4 (31 species), respec- tively. Twelve species of butterflies were recorded from transects at the lower altitudinal site (Transect 1 and 2) with the most frequently and commonly observed species among them being Belenois aurota (Fabricius), Catopsilia pomona Linnaeus, Aporia agathon phryxe (Boisduval), Euploea core (Cramer), Phalanta phalantha (Drury) while species such as Lasiommata schakra (Kollar), Danaus chryssippus (Linnaeus), Pseudoergolis wedah (Kollar), Ochlodes brahma Moore and Tagiades cohaerens cynthia Evans were recorded occasionally with 11 to 20 number of sightings. Four species of butterflies Aulocera padama Kollar, Kallima inachus Boisduval, Pontia daplidice (Linnaeus) and Udara dilectus Moore with varied degree of recorded relative abundance were restricted to the higher altitudinal site. In comparison with the findings of Hannyngton (1910-11), all recorded species have a wide distribution in the Kumaon Himalayan region. No endemism in the species was recorded. However,

Table 4: Various diversity indices calculated for the butterfly community across different transects in BWLS.

\begin{tabular}{|lllllll|}
\hline Diversity indices & Transect 1 & Transect 2 & Transect 3 & Transect 4 & Low Altitude Site & High Altitude Site \\
\hline Species number & 41 & 40 & 32 & 31 & 42 & 34 \\
Individuals & 1101 & 703 & 499 & 288 & 1804 & 787 \\
Simpson D & 0.947 & 0.9293 & 0.9179 & 0.9205 & 0.9412 & 0.9204 \\
Shannon- Wiener & 3.339 & 3.138 & 2.959 & 2.942 & 3.283 & 2.993 \\
Evenness & 0.6872 & 0.5765 & 0.6026 & 0.6115 & 0.6345 & 0.5864 \\
Margalef & 5.711 & 5.949 & 4.99 & 5.298 & 5.468 & 4.949 \\
Berger Parker & 0.1544 & 0.1707 & 0.1804 & 0.1667 & 0.1608 & 0.1753 \\
\hline
\end{tabular}

Bray.Curts Cluster Analysis [Single Link)

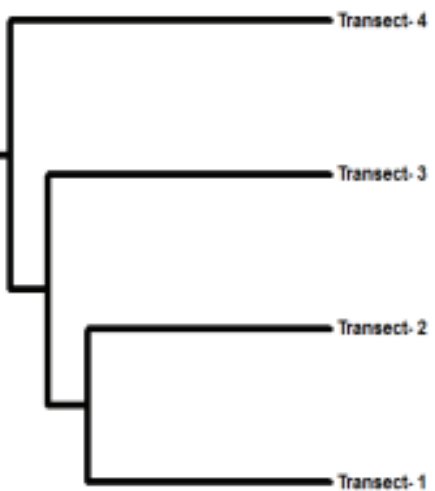

0. * Similurity

50.

100

Fig. 2: Bray Curtis cluster analysis of quantitative data on butterflies. 
five species are legally protected under the Indian Wildlife Protection Act of 1972 namely, Neptis sankara (Kollar) under Schedule I, Aporia agathon agathon (Gray), Neptis zaida Westwood and Pontia daplidice (Linnaeus) under Schedule II and Euploea core (Cramer) under Schedule V (Anonymous 2006).

It is a well-studied aspect of Lepidopteran ecology that habitats at the lower elevations yield more number of species than those at the higher elevations (Lien 2013). The significant differences in the values of the Shannon diversity index as a measure of alpha diversity along altitudes were observed during the study period (Table 4). The calculated diversity value was higher for Transect 1 (3.339), followed by Transect 2 (3.138), Transect 3 (2.959) and Transect 4 (2.942), respectively. The low dominance values indicate that species of butterflies were distributed more or less evenly across transects. Such values indicate a significant decrease in species richness and diversity of butterflies with the increase in altitude supporting the observations made by Lewis et al. (1998), Lien (2013) and Joshi \& Arya (2007). The similarity of species composition among different transects has also been presented in Fig. 2. The similarity matrix from the quantitative data showed that taxonomic composition of butterflies was much similar in the mixed oak forests of transects that were laid at the lower altitudinal site, corresponding to the value of $76.82 \%$, followed by Transect 2 and Transect 3 with a similarity index value of $73.04 \%$. Transect 4 laid at high altitude in the hilltop grassland stood out clearly showing linkage at the similarity matrix value of $39.16 \%$. The overall observations made in the present study suggest that habitat complexity, floral diversity and climatic variables such as temperature and relative humidity associated with each transect might act as major drivers and determinants of the altitudinal patterns of butterfly assemblages in the sanctuary.

Protected areas are critical for nature conservation and maintaining ecosystem services and thus inventorying biodiversity in such zones is of prime importance (Vina $\&$ Liu 2017). Owing to the diversified vegetation pattern along altitudes, the sanctuary provides sufficient natural resources required for survival of a good range of butterflies throughout the year. Despite the religious, cultural and biological significance of the BWLS, it remained a low profiled protected area of the state Uttarakhand. The unplanned and improper tourism management and tremendous pressure from factors such as slash and burn system, the prevalence of frequent forest fires especially in the pine forests during summers, overgrazing mainly close to the lower altitudinal zone of the sanctuary, pose potential threats of regional loss and extinction of biodiversity. Thus, our study suggests that the region must be monitored for other biological resources which would assist in managing and preserving endangered flora and fauna as well as in strengthening the status of the sanctuary. The preliminary results on butterflies revealed in the present study are also expected to provide necessary information to the conservation planning authorities for proper management of the BWLS while also allowing scope and direction for future research and opportunities of ecotourism in the sanctuary.

\section{ACKNOWLEDGMENTS}

The authors would like to thank Head, Department of Zoology, D.S.B. Campus, Kumaun University, Nainital, for providing necessary facilities and suggestions. In addition, thanks to the Forest Department, Almora, Uttrakhand, for granting permission to carry out our research and for logistical support during the study.

\section{REFERENCES}

Acharya, B.K. and Vijayan, L. 2015. Butterfly diversity along the elevation gradient of Eastern Himalaya, India. Ecological Research, 30: 909-919.

Anonymous 2006. The Wildlife (Protection) Act, 1972. Natraj Publishers, Dehradun, pp. 253.

Arora, G.S. 1995. Lepidoptera: Rhopalocera. In: Fauna of Nanda Devi Biosphere Reserve, Ecosystem Series. Zoological Survey of India, Calcutta, 1, pp. 61-73.

Arora, G.S. 1994. Lepidoptera: Butterflies. In: Fauna of Rajaji National Park, Fauna of Conservation Areas. Zoological Survey of India, Calcutta, 5, pp. 245-300.

Arya, M.K., Verma, A. and Neha 2018. Biodiversity assessment of butterflies in Kumaun Lesser Himalayan oak forest for promoting ecotourism at city Nainital. Journal of Himalayan Ecology and Sustainable Development, 13: 75-95.

Arya, M.K. 2015. Observations on trophic levels of different groups of insect population vis a vis insect pollinators in a protected forest ecosystem in the Western Himalayas. Journal of Experimental Zoology India, 18(1): 271-277.

Arya, M.K. and Dayakrishna 2017. Species richness and diversity of butterflies in the landscape of Nandhaur Wildlife Sanctuary, Nainital, Uttarakhand. Journal of Environment and Bio-Sciences, 31(2): 307-315.

Bhardwaj, M. and Uniyal, V.P. 2013. High-altitude butterfly fauna of Gangotri National Park, Uttarakhand: Patterns in species, abundance composition and similarity. Envis Bulletin: Arthropods and Their Conservation in India (Insects and Spiders), 14(1): 38-48.

Chowdhury, S. 2014. Butterflies of Sundarban Biosphere Reserve, West Bengal, Eastern India: A preliminary survey of their taxonomic diversity, ecology and their conservation. Journal of Threatened Taxa, 6(8): 6082-6093.

FSI 2011. State of Forest Reports, Forest Survey of India, Dehradun, India. Hammer, O., Harper, D.A.T. and Ryan, P.D. 2014. PAST-PAlaeontological STatistics Version 3.04.

Hannyngton, F. 1910-11. Butterflies of Kumaun. Journal of Bombay Natural History Society, 20(3): 871-872.

Haribal, M. 1992. The Butterflies of Sikkim: Himalayas and their Natural History. Sikkim Nature Conservation Foundation, Gangtok, Sikkim, pp. 217.

Hill, J.K., Thomas, C.D., Fox, R., Telfer, M.G., Willis, S.G., Asher, J. and Huntley, B. 2002. Responses of butterflies to twentieth century climate warming: Implications for future ranges. Proceedings of Royal Society B, 269: 2163-2171. 
Ilyas, O. 1998. People and Protected Area-The case of Binsar Wildlife Sanctuary. World Wide Fund for Nature-New Delhi, India, pp. 54.

Joshi, P.C. and Arya, M. 2007. Butterfly Communities along altitudinal gradients in a Protected Forest in the Western Himalayas, India. The Natural History Journal of Chulalongkorn University, 7(1): 1-9.

Joshi, P.C. 2007. Community structure and habitat selection of butterflies in Rajaji National Park, a moist deciduous forest in Uttaranchal, India. Tropical Ecology, 48(1): 119-123.

Joshi, P.C., Kothari, K., Badoni, V.P., Arya, M. and Agarwal, A. 2004. Species composition and density of entomofauna vis a vis altitudinal variations and disturbances in Nanda Devi Biosphere Reserve, Uttaranchal, India. Asian Journal of Microbiology, Biotechnology and Environmental Science, 6(2): 301-308.

Joshi, P.C., Kumar, K. and Arya, M. 2008. Assessment of insect diversity along an altitudinal gradient in Pindari forests of Western Himalaya, India. Journal of Asia-Pacific Entomology, 11: 5-11.

Kala, C.P. and Majila, B.S. 2013. Status of the forest and wildlife in the Binsar Wildlife Sanctuary. In: Kala, C.P., and Silori, C.S. (eds.), Biodiversity Communities and Climate Change. TERI Publication, New Delhi, India, pp. 25-35.

Kehimkar, I. 2014. The Book of Indian Butterflies. Bombay Natural History Society: Oxford University Press, pp. 497.

Kumar, K., Joshi, P.C. and Arya, M. 2017. Variation in population density and biomass of butterflies in Nanda Devi Biosphere Reserve (NDBR), West Himalaya, Uttarakhand. Journal of Environment \& Bio-Sciences, 31(1): 9-16.

Kumar, P. 2008. Insecta: Lepidoptera (Rhopalocera). In: Fauna of Corbett Tiger Reserve, Conservation Area Series. Zoological Survey of India, Kolkata, 35, pp. 205-220.

Kunte, K. 2000. Butterflies of Peninsular India. Universities Press, Hyderabad.

Lambshead, P.J.D., Paterson, G.L. J. and Gage, J.D. 1997. Biodiversity Professional, Version 2.0. The Natural History Museum and The Scottish Association for Marine Science.

Lewis, O.T., Wilson, R.J. and Harper, M.C. 1998. Endemic butterflies on Grande Comore: Habitat preferences and conservation priorities. Biological Conservation, 85: 113-121.

Lien, V.V. 2013. The effect of habitat disturbance and altitudes on the diversity of butterflies (Lepidoptera: Rhopalocera) in a tropical forest of Vietnam: Results of a long-term and large scale study. Russian Entomological Journal, 22 (1): 51-65.

Magurran, A.E. 1988. Ecological Diversity and its Measurement. Princeton University Press, Princeton, New York.

Mascia, M.B. and Pailler, S. 2010. Protected area downgrading, downsizing and degazettement (PADDD) and its conservation implications. Conservation Letters, 00: 1-12.

New, T.R. 2011. Launching and steering flagship Lepidoptera for conservation benefit. Journal of Threatened Taxa, 3(6): 1805-1817.

Pandey, P., Joshi, P.C. and Kaushal, B.R. 2013. Role of insects in sustaining a forest ecosystem in Western Himalaya, India. Journal of Applied Biosciences, 39(1): 1-22.

Pollard, E. 1979. A national scheme for monitoring the abundance of butterflies. The First Three Years British Entomological and Natural History Society. Proceedings and Transactions, 12: 77-99.

Pollard, E. and Yates, T.J. 1993. Monitoring butterflies for Ecology and Conservation. Chapman and Hall, London.

Qureshi, A.A., Bhagat, R.C. and Bhat, D.M. 2014. Diversity of butterflies (Lepidoptera: Papilionoidea and Hesperoidea) of Dachigam National Park, Jammu and Kashmir, India. Journal of Threatened Taxa, 6(1): 5389-5392.

Rawal, R.S. and Dhar, U. 2001. Protected area network in Indian Himalayan region: Need for recognizing values of low profile protected areas. Current Science, 81(2): 175-184.

Rodgers, W.A. and Panwar, H.S. 1988. Planning a Wildlife Protected Area Network in India. Vol. I. The Report, Wildlife Institute of India, Dehradun.

Singh, A.P. 2009. Butterflies of Kedarnath Musk Deer Reserve, Garhwal Himalaya, India. Journal of Threatened Taxa, 1(1): 37-48.

Singh, A.P. and Sondhi, S. 2016. Butterflies of Garhwal, Uttarakhand, Western Himalaya, India. Journal of Threatened Taxa, 8(4): 8666-8697.

Smetacek, P. 2012. Butterflies (Lepidoptera: Papilionoidea and Hesperoidea) and other protected fauna of Jones Estate, a dying watershed in the Kumaon Himalaya, Uttarakhand, India. Journal of Threatened Taxa, 4(9): 2857-2874.

Sondhi, S. and Kunte, K. 2016. Butterflies (Lepidoptera) of the Kameng protected area complex, Western Arunachal Pradesh, India. Journal of Threatened Taxa, 8 (8): 9053-9124.

Sondhi, S. and Kunte, K. 2018. Butterflies of Uttarakhand- A Field Guide. Bishen Singh Mahendra Pal Singh (Dehradun), Titli Trust (Dehradun) National Centre for Biological Sciences (Bengaluru), pp. 310.

Tayal, A., Nirwani, D. and Jabin, S. 2015. Disaster Management-Uttarakhand floods in India a case study. Journal of Energy Research and Environmental Technology, 2(2): 89-93.

Tewari, R. and Rawat, G.S. 2013. Butterfly fauna of Jhilmil Jheel Conservation Reserve, Haridwar, Uttarakhand, India. Biological Forum: An International Journal, 5(2): 22-26.

Tiple, A.D., Deshmukh, V.P. and Dennis, R.L.H. 2006. Factors influencing nectar plant resource visits by butterflies on a university campus: implications for conservation. Nota Lepidopteralogica, 28(3/4): 213-224.

Uniyal, V.P. and Mathur, P.K. 1998. Diversity of butterflies in the great Himalayan National Park, Western Himalaya. Indian Journal of Forestry, 21(2): 150-155.

Uniyal, V.P., Bhardwaj, M. and Sanyal, A.K. 2013. An Assessment of Entomofauna for Management and Conservation of Biodiversity in the Gangotri Landscape. Annual Progress Report, Wildlife Institute of India, Dehradun, pp. 237.

Vina, A. and Liu, J. 2017. Hidden roles of protected areas in the conservation of biodiversity and ecosystem services. Ecosphere, 8(6): 1-16. 